\title{
RNase H-Assisted Imaging of Peroxynitrite in Living Cells with 5'-Boronic Acid Modified DNA
}

Maëva Reverte, $\dagger$ Anaïs Vaissiere, $\neq$ Prisca Boisguerin,$\neq$ Jean-Jacques Vasseur, $\dagger$ and Michael Smietana $*$,

† Institut des Biomolécules Max Mousseron (IBMM), UMR 5247 CNRS, Université de Montpellier, ENSCM, Place Bataillon, CC1704 34095 Montpellier, France

$\neq$ Centre de Recherche de Biologie Cellulaire de Montpellier, UMR 5267 CNRS, 1919 Route de Mende, 34293 Montpellier, France

\section{Table of Contents}

List of Tables and Figures

S2

General experimental section

S3

Synthesis of boronooligonucleotides

S4

Analysis of oligonucleotides

S5

Preparation of ROS

S6

$\begin{array}{ll}\text { Native Polyacrylamide Gel Electrophoresis } & \text { S7 }\end{array}$

$\begin{array}{ll}\text { RNase H experiment } & \text { S8 }\end{array}$

$\begin{array}{ll}\text { Fluorescence experiments } & \text { S11 }\end{array}$

$\begin{array}{ll}\text { Cell culture and fluorescence imaging } & \text { S13 }\end{array}$ 


\section{$\underline{\text { List of Tables and Figures }}$}

Table S1. Coupling conditions for oligonucleotides syntheses

Table S2. MALDI MS of synthesized ONs

Table S3. Reagent volumes for a $40 \mathrm{~mL}$ gel

Figure S1. Kinetic degradation monitored by HPLC of A) ODN1/ORN1 and B) ODN2/ORN1.

Figure S2. Kinetic degradation monitored by HPLC of hybrid duplex formed by a 6mer boronic acid modified DNA (ODN4) and a 21mer RNA template (ORN1) in the presence of RNase $\mathrm{H}\left(10 \mathrm{U}, 37^{\circ} \mathrm{C}\right)$.

Figure S3. Fluorescence control experiments

Table S4. Determination of LOD 


\section{General}

All reagents were purchased from Aldrich or local suppliers and used without purification. All oligonucleotides used for this study were performed in $1 \mu \mathrm{mol}$ scale using ABI 381A DNA synthesizer by classical phosphoramidite chemistry. All oligonucleotides were analyzed by RP-HPLC (Dionex Ultimate 3000) with an Accucore aQ C18 column (50x4.6 mm; Thermoscientific) and by MALDI-TOF MS

(Voyager PerSeptive Biosystems) using trihydroxyacetophenone or 3hydroxypicolinic acid as matrix and ammonium citrate as co-matrix. Native PAGE experiments were performed on a Hoefer SE600X apparatus and revealed with GelRed Nucleic Acid Gel Stain using E-BOX-VX5/20MX. Thermal denaturation experiments were performed on a VARIAN Cary 300 UV spectrophotometer equipped with Peltier temperature controller and thermal analysis software. Fluorescence experiments were performed on a spectrofluorometer FP-8300 (Jasco Inc.). Epifluorescence microscopy was performed with an Evos FL fluorescent microscope (Life Technologies, Burlington, Canada) $\left(\lambda_{\text {excitation }}: 531-540 \mathrm{~nm}, \lambda_{\text {emission }}\right.$ : 593-640 nm). 


\section{Synthesis of boronooligonucleotides}

Syntheses were performed in $1 \mu \mathrm{mol}$ scale using ABI 381A DNA synthesizer by phosphoramidite chemistry with conditions described in Table S1. A commercial 3'BHQ-1 CPG 1000 support (link technologie) was used for the synthesis of ODN3 (5'$\mathrm{T}^{\mathrm{bn}}$ GAATACAAATT-3'-BHQ-1) and dTbn-phosphoramidite was synthesized and incorporated at the 5 '-end of ODN3 according to previous records. ${ }^{1}$

Table S1. Coupling conditions for oligonucleotide syntheses.

\begin{tabular}{cllc}
\hline Step & Reaction & Reagent & Time (s) \\
\hline 1 & Deblocking & $3 \%$ TCA in DCM & 35 \\
2 & Coupling & $0.1 \mathrm{M}$ amidite in $\mathrm{CH}_{3} \mathrm{CN}+0.3 \mathrm{M} \mathrm{BMT}$ in $\mathrm{CH}_{3} \mathrm{CN}$ & 180 \\
3 & Capping & $\mathrm{Ac}_{2} \mathrm{O} / \mathrm{THF} /$ Pyridine $+10 \% \mathrm{NMI}$ in THF & 8 \\
4 & Oxidation & $0.1 \mathrm{M} \mathrm{I}_{2}$ in $\mathrm{THF} / \mathrm{H}_{2} \mathrm{O} /$ Pyridine & 15 \\
\hline
\end{tabular}

1 Martin, A.R.; Mohanan K.; Luvino D.; Floquet, N.; Baraguey C.; Smietana M.; Vasseur J.J. Expanding the borononucleotide family: synthesis of borono-analogues of dCMP, dGMP and dAMP, Org. Biomol. Chem. 2009, 7, 4369-4377. 
MALDI-TOF MS Analysis of oligonucleotides used in this study

All oligonucleotides synthesized were analyzed by MALDI-TOF MS and the results are presented in the table below (Table S2).

Table S2. MALDI MS of synthesized ODNs.

\begin{tabular}{|c|c|c|c|}
\hline ODNs & Sequence & $\begin{array}{c}\text { Calcld } m / z^{a} \\
{[\mathrm{M}+\mathrm{H}]^{+}}\end{array}$ & $\begin{array}{l}\mathrm{Obs} m / z \\
{[\mathrm{M}+\mathrm{H}]^{+}}\end{array}$ \\
\hline ODN1 & $5^{\prime}-T^{\mathrm{bn}}$ GAATACAAATT & 3657.2 & 3657.6 \\
\hline ODN2 & 5'-TGAATACAAATT & 3651,4 & 3651,6 \\
\hline ODN3 & $5^{\prime}$-T ${ }^{\mathrm{bn}}$ ATATTCATCATAG-BHQ-1 & 4795,7 & 4794,9 \\
\hline ODN4 & $5^{\prime}-\mathrm{T}^{\mathrm{bn}} \mathrm{ACAAA}$ & 1748,3 & 1747,9 \\
\hline ODN5 & 5'-TATATTCATCATAG-BHQ-1 & 4790,9 & 4791,3 \\
\hline ODN6 & 5'- T ${ }^{\mathrm{bn}}$ ATATTCATCATAG & 4242,5 & 4242,8 \\
\hline ODN7 & 5'- TATATTCATCATAG & 4236,9 & 4236,7 \\
\hline ORN1 & 5'-UUUGUAUUCAGCCCAUAUCUU & 6531,8 & 6532,1 \\
\hline \multirow[t]{2}{*}{ ORN2 } & 5'-6FAM- & 9686,9 & 9687,4 \\
\hline & CUAUGAUGAAUAUAGAUACAGAAGCGUCAU & & \\
\hline
\end{tabular}




\section{Preparation of different ROS solutions}

\section{Preparation of $\mathrm{NO}_{2}=$}

The source of $\mathrm{NO}_{2}^{-}$was sodium nitrite

$\underline{\text { Preparation of } \mathrm{NO}_{3}}=$

The source of $\mathrm{NO}_{3}{ }^{-}$was potassium nitrate

\section{$\underline{\text { Preparation of } \mathrm{H}_{2} \underline{\mathrm{O}}_{2}}$}

The stock solution was purchased and the concentration of $\mathrm{H}_{2} \mathrm{O}_{2}$ was titrated according to iodometry.

\section{Preparation of $\mathrm{OCl}^{-}$}

Commercial bleach was the source of $\mathrm{NaOCl}$. The concentration of $\mathrm{OCl}^{-}$was determined by titration with $\mathrm{S}_{2} \mathrm{O}_{3}{ }^{2-}$.

\section{Preparation of peroxynitrite}

A solution mixing $0.6 \mathrm{M} \mathrm{KNO} 2,0.6 \mathrm{M}$ in $\mathrm{HCl}, 0.7 \mathrm{M}$ in $\mathrm{H}_{2} \mathrm{O}_{2}$ and $3 \mathrm{M} \mathrm{NaOH}$ was prepared at $0^{\circ} \mathrm{C}$. The peroxynitrite concentration was estimated by using an extinction coefficient of $1670 \mathrm{~mol} / \mathrm{L}^{-1}$ at $302 \mathrm{~nm}$. 


\section{Native Polyacrylamide Gel Electrophoresis}

Native PAGE experiments were performed with polyacrylamide gels $(18.5 \times 16.4 \mathrm{~cm}$, $0,75 \mathrm{~mm}$ of thickness) prepared by mixing: TrisBorate EDTA (TBE) $1 \mathrm{X}$ solution, ammonium peroxodisulfate (APS), Acrylamide/N,N'-methylenebisacrylamide (19/1 $\mathrm{v} / \mathrm{v}$ ), and $N, N, N^{\prime}, N^{\prime}$-tetramethyl-ethylenediamine (TEMED) in proportion shown below (Table S3). 20\% polyacrylamide gels were used for the migration of single strand DNA and $15 \%$ polyacrylamide gels were used for DNA duplexes. Freshly casted gels were pre-runned at constant power of $20 \mathrm{~W}$ for 30 min at $4^{\circ} \mathrm{C}$. After loading of the samples the run were performed at constant power of $20 \mathrm{~W}$ for $1 \mathrm{~h}$ at $4^{\circ} \mathrm{C}$. The gels were revealed for the single strand using GelStain and for the duplex with GelRed Nucleic Acid Gel Stain. The bands were observed using E-BOXVX5/20MX with vision capt software.

Table S3. Reagent volumes for a $40 \mathrm{~mL}$ gel

Reagent Quantity

Volume of Acrylamide/ $N, N^{\prime}$-methylenebisacrylamide

$\begin{array}{ll}\text {-For a } 20 \% \text { gel } & 20 \mathrm{~mL} \\ \text {-For a } 15 \% \text { gel } & 15 \mathrm{~mL}\end{array}$

APS

$400 \mathrm{mg}$

TEMED

$20 \mu \mathrm{L}$

TBE buffer $1 \mathrm{X}$

QSP $40 \mathrm{~mL}$ 


\section{RNAse H experiments}

In a typical experiment, $1 \mu \mathrm{L}$ of $200 \mu \mathrm{M}$ of each partner in commercial buffer $1 \mathrm{X}$ (final volume $100 \mu \mathrm{L}$; pH 8.3) was mixed with $10 \mathrm{U}$ of RNase $\mathrm{H}$ (New England Biolabs) and incubated at $37^{\circ}$.

Figure S1. Kinetic degradation monitored by HPLC of A) ODN1/ORN1 and B) ODN2/ORN1.

A)
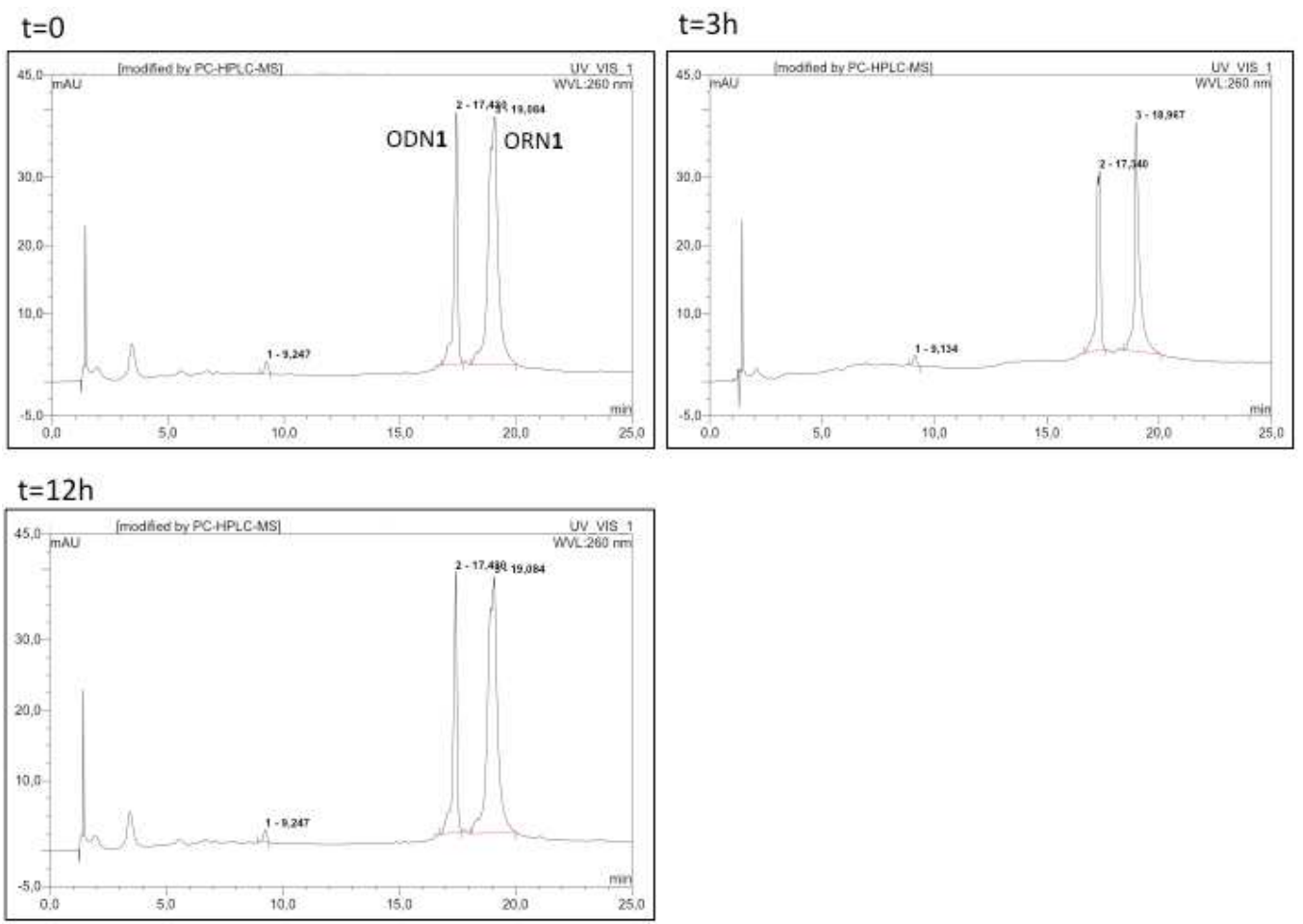
B)
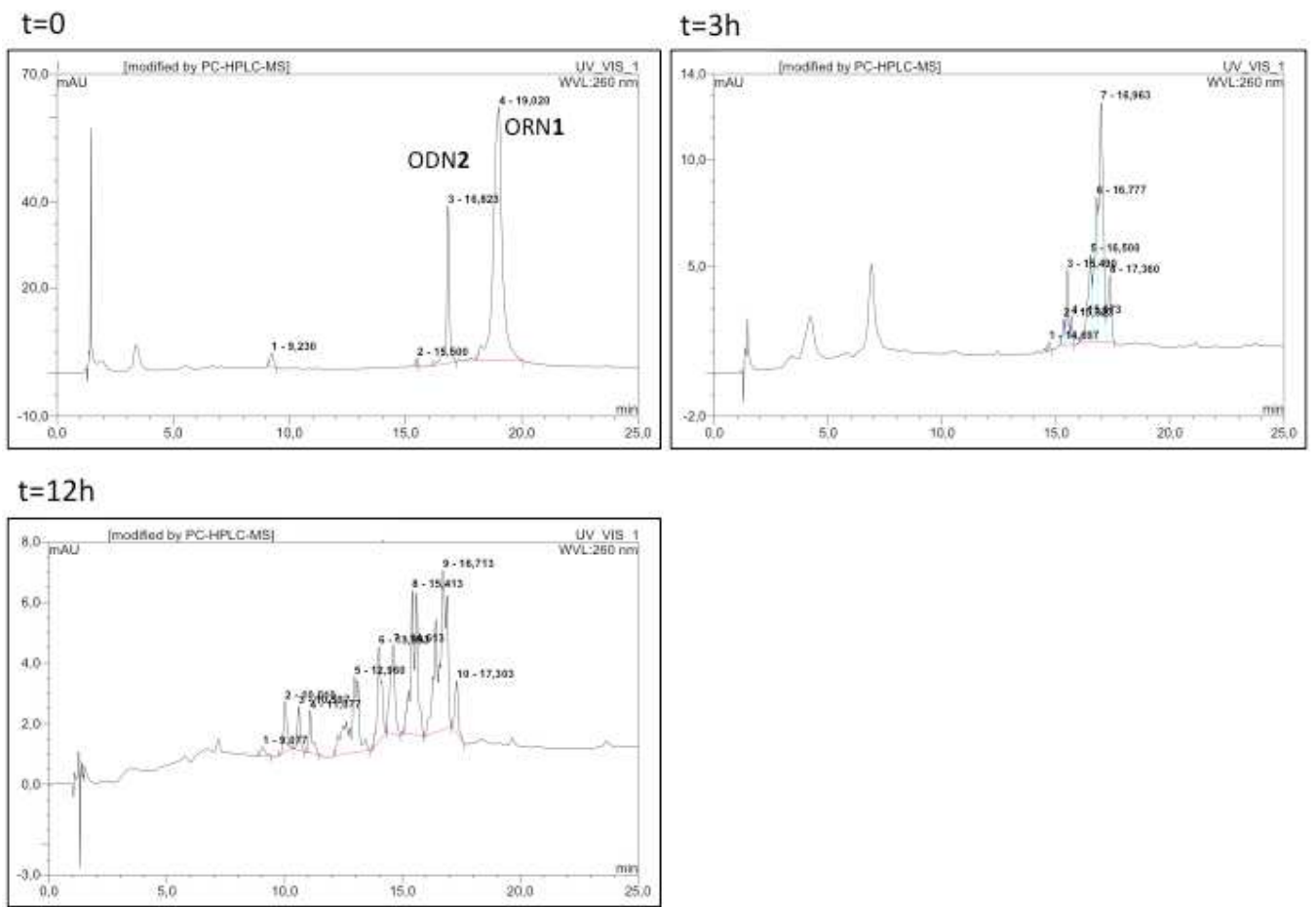

Figure S2. Kinetic degradation monitored by HPLC of hybrid duplexes formed by a 6mer boronic acid modified DNA (ODN4) and a 21mer RNA template (ORN1) in the presence of RNase $\mathrm{H}\left(10 \mathrm{U}, 37^{\circ} \mathrm{C}\right)$. 

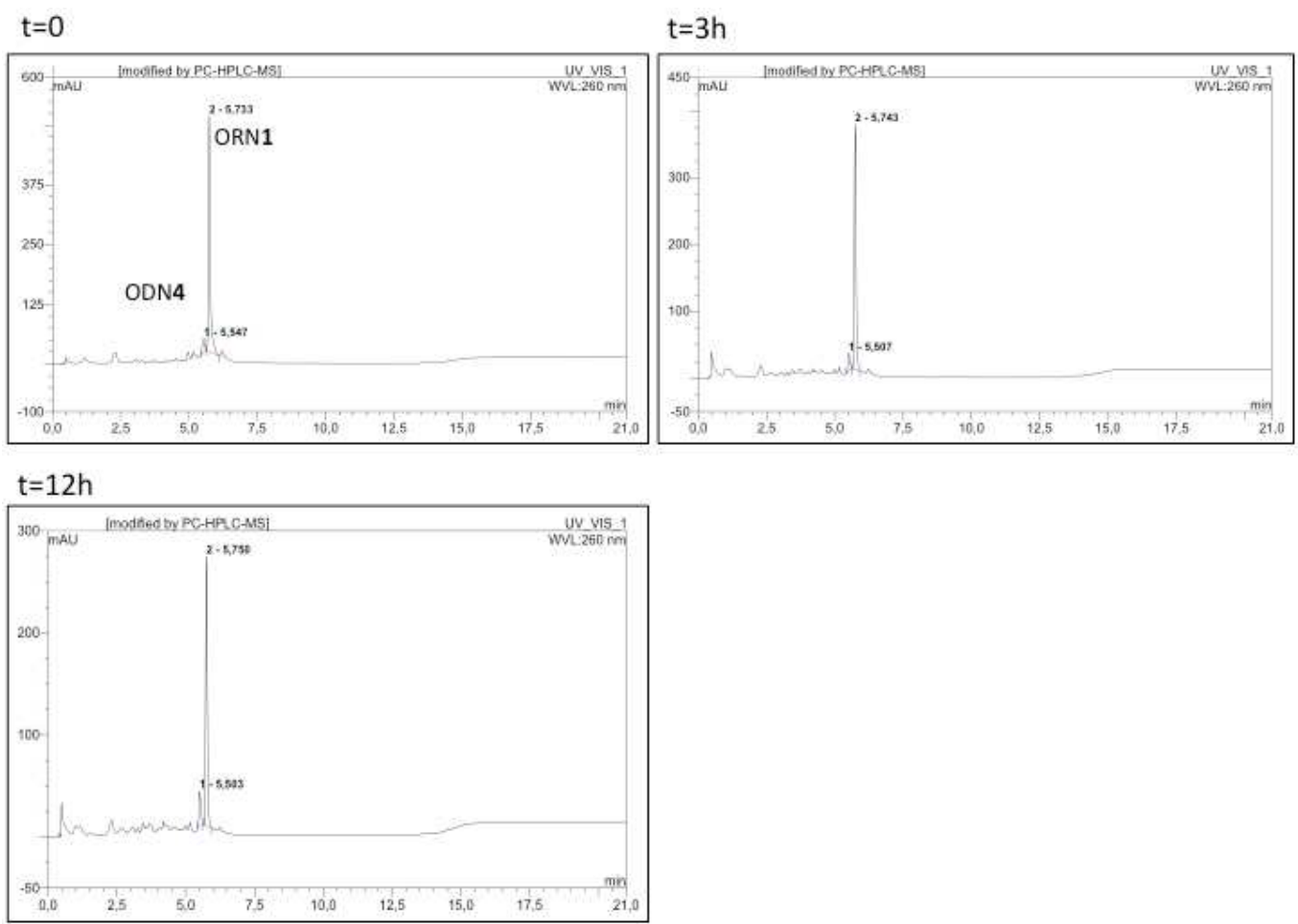


\section{Fluorescence experiments}

The RNase H experiment was performed as described page S8. After 15 minutes of incubation at $37^{\circ} \mathrm{C}$, the fluorescence measurement was performed at $37^{\circ} \mathrm{C}$ in a $100 \mu \mathrm{L}$ Quartz SUPRASIL cell and the fluorescence signal was collected from 500 to 600 nanometers.

Control experiments :
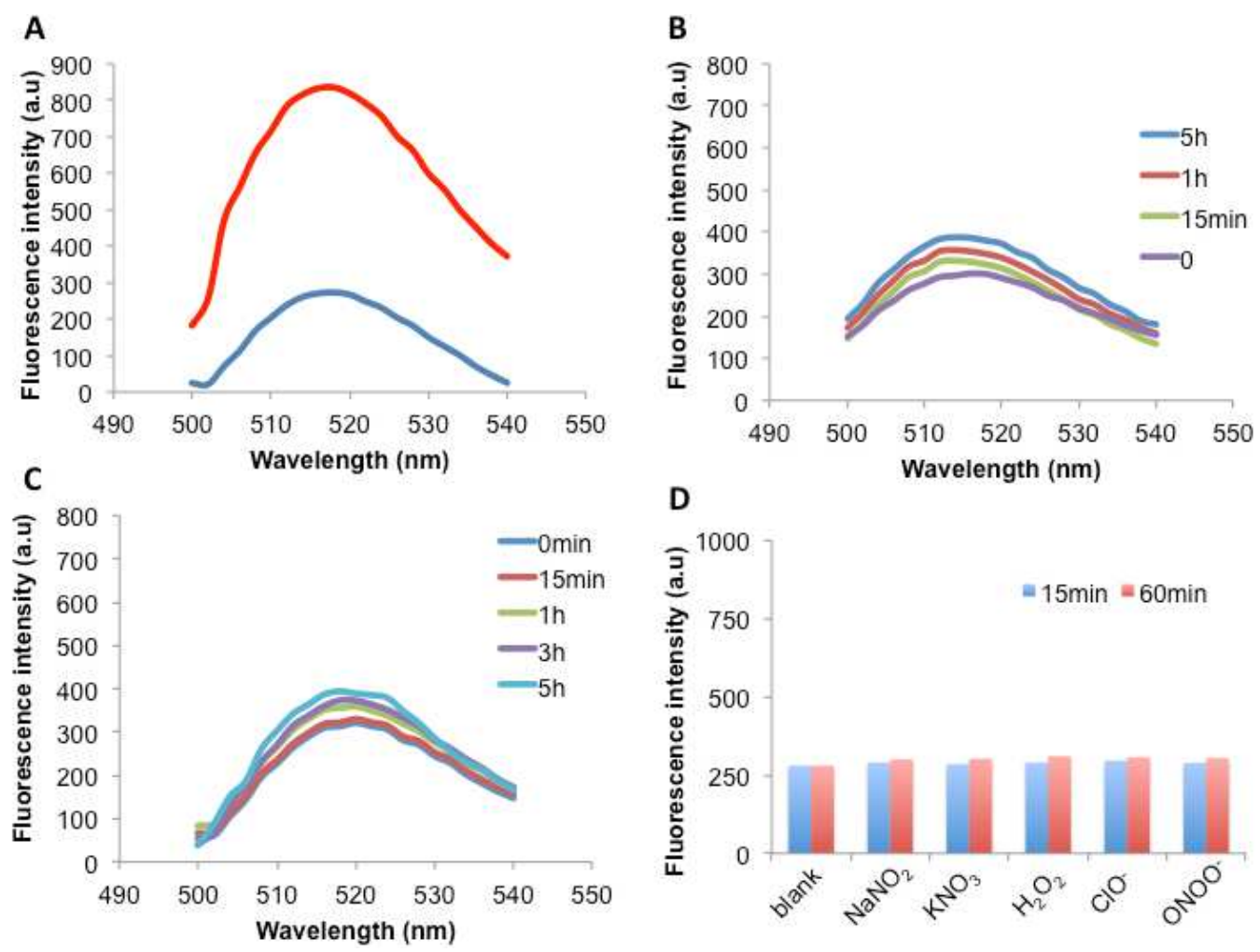

Figure S3. Fluorescence control experiments A) Fluorescence spectra of ORN2 (2 $\mu \mathrm{M})$ before (red) and after (blue) the addition of ODN3 $(2 \mu \mathrm{M})$ at $498 \mathrm{~nm}$. B) Fluorescence spectra of duplex ODN3/ORN2 (2 $\mu \mathrm{M}$ of each probe) at $37^{\circ} \mathrm{C}$ at different times. C) Fluorescence spectra of duplex ODN3/ORN2 $(2 \mu \mathrm{M}$ of each probe) in the presence of RNase $\mathrm{H}(10 \mathrm{U})$ at $37^{\circ} \mathrm{C}$ at different times. D) Fluorescence spectra of duplex ODN3/ORN2 (2 $\mu \mathrm{M}$ of each probe) in the presence of RON/ROS $\left(100 \mu \mathrm{M}\right.$ ) at $37^{\circ} \mathrm{C}$ at $15 \mathrm{~min}$ (in blue) and $60 \mathrm{~min}$ (in red) in the absence of RNase $\mathrm{H}$. 


\section{Determination of the Limits of Detection (LODs)}

To determine the LOD for the bonus addition of $\mathrm{ONOO}^{-}$, different concentrations of $\mathrm{ONOO}^{-}$were added to the mixture. Fluorescence intensity was determined at 15 minutes after mixing.

Data were recorded as mean \pm standard deviation based on three independent measurements. The linear response range was determined and used to derive LOD. The LOD was calculated based on the standard deviation of the response of $y-$ intercept (SD) and the slope of the calibration curve (S) according to the formula: $\mathrm{LOD}=3.3(\mathrm{SD} / \mathrm{S})$. The values of $\mathrm{SD}$ and slope was obtained from the LINEST function by creating a calibration curve in Microsoft Excel.

Table S4. Determination of LOD

\begin{tabular}{|c|c|c|c|c|c|c|c|}
\hline $\begin{array}{c}\text { Time } \\
(\mathbf{m i n})\end{array}$ & $\begin{array}{c}\text { Linearity } \\
\text { range } \\
(\boldsymbol{\mu M})\end{array}$ & Slope & $\begin{array}{c}\text { SD } \\
\mathbf{( s l o p e )}\end{array}$ & $\begin{array}{c}\mathbf{y}- \\
\text { intercept }\end{array}$ & $\begin{array}{c}\text { SD (y- } \\
\text { intercept) }\end{array}$ & $\begin{array}{c}\text { Regression } \\
\text { coefficient }\end{array}$ & $\begin{array}{c}\text { LOD } \\
(\boldsymbol{\mu M})\end{array}$ \\
\hline 15 & $0,1-10$ & 22,7 & 0,32 & 34,06 & 1,86 & 0,99 & 0,270 \\
\hline 60 & $0,1-10$ & 30,46 & 0,045 & 204,56 & 0,26 & 0,99 & 0,028 \\
\hline
\end{tabular}




\section{Cell culture and fluorescence imaging}

\section{$\underline{\text { Cell culture }}$}

Cells were cultured in RPMI 1640 1X supplemented with heat-inactivated $10 \%$ of fetal bovide serum (FBS) and $1 \%$ penicillin-streptomycin antibiotics, pyruvate and LGlutamine. All cells were kept in $5 \% \mathrm{CO}_{2}$ at $37{ }^{\circ} \mathrm{C}$. Fluorescence microscopy was performed with a Evos FL cell imaging system $\left(\lambda_{\text {excitation }}: 531-540 \mathrm{~nm}, \lambda_{\text {emission }}: 593-\right.$ $640 \mathrm{~nm})$.

\section{$\underline{\text { Cellular uptake }}$}

We first evaluated the cellular uptake of non-modified ODN7/ORN2 and modified ODN6/ORN2 hybrid duplexes. 24 h before experiments, RAW 264.7 macrophages cells were seeded on 24-well plates. RPMI medium is then removed and the cells are loaded in serum-free DMEM bright medium. Cells were transfected with RNA:DNA duplexes (150 nM final concentration) using the N-Ter Nanoparticle Transfection System (Sigma Aldrich) and incubated for $4 \mathrm{~h}$ at $37^{\circ} \mathrm{C}, 5 \% \mathrm{CO}_{2}$. RNA:DNA duplexes uptake was observed by fluorescence microscopy $\left(\lambda_{\text {excitation }}: 531-540 \mathrm{~nm}, \lambda_{\text {emission }}\right.$ : 593-640 nm) thus confirming the presence of intracytoplasmic duplexes.

Imaging exogenously added $\mathrm{ONOO}^{-}$in Raw 267.4 macrophage cells.

RAW 264.7 macrophages cells were seeded on 24-well plates in serum-free DMEM bright medium and transfected with ODN3/ORN2 for $4 \mathrm{~h}$. The medium was then removed and cells were loaded in $200 \mu \mathrm{L}$ of DMEM bright medium supplemented by $10 \%$ of FBS. A solution of $2 \mathrm{X} \mathrm{ONOO}^{-}$in PBS $(200 \mu \mathrm{L})$ was added to the cells $(1 \mu \mathrm{M}$ final concentration). 
$\underline{\text { Imaging Endogenous generated ONOO- in Raw } 267.4 \text { macrophage cells. }}$

RAW 264.7 macrophages cells were seeded on 24-well plates in RPMI 10\% FBS. The cells were pretreated during $12 \mathrm{~h}$ with LPS $\left(1 \mu \mathrm{g} \cdot \mathrm{mL}^{-1}\right)$ and IFN- $\gamma\left(50 \mathrm{ng} \cdot \mathrm{mL}^{-1}\right)$ and then transfected with ODN3/ORN2. Intracellular fluorescence was observed after $4 \mathrm{~h}$ of incubation.

For inhibition assays, the cells were activated with LPS $\left(1 \mu \mathrm{g} \cdot \mathrm{mL}^{-1}\right)$ and IFN-v (50 ng. $\left.\mathrm{mL}^{-1}\right)$ in the presence of aminoguanidine ( $5 \mathrm{mM}$ final concentration) or TEMPO (300 $\mu \mathrm{M}$ final concentration) during $12 \mathrm{~h}$ and then transfected with ODN3/ORN2. 